\title{
GAYA KEPEMIMPINAN DAN MOTIVASI TERHADAP KINERJA PEGAWAI DI LEMBAGA AMIL ZAKAT MARHAMAH MAIMANAH
}

Ade Kohar

STAI Al Hidayah Bogor

adekohar.staia@gmail.com

\section{ABSTRAK}

Dalam pencapaian tujuan serta sukses tidaknya sebuah perusahaan atau organisasi banyak unsur penting yang berperan dalam pemenuhannya, diantaranya adalah kepemimpinan, kinerja, dan motivasi. Kinerja suatu organisasi, baik non profit maupun lembaga profit tidak mungkin akan mencapai titik hasil yang optimal tanpa adanya motivasi dari pemimpin organisasi yang bersangkutan. Kepemimpinan dan gaya kepemimpinan dalam organisasi sangat berperan dalam mempengaruhi kinerja karyawan. Faktor-faktor yang berpengaruh terhadap kinerja karyawan, salah satunya adalah motivasi. Dengan motivasi yang tepat maka akan mendorong peningkatan kinerja yang lebih baik dan akhirnya tujuan perusahaan akan mudah dicapai. Faktor-faktor yang mempengaruhi motivasi seseorang adalah melakukan hal yang penting, apresiasi secara penuh, perasaan memiliki sesuatu, keamanan kerja, upah, promosi dan karir dalam orgnanisasi, kondisi kerja yang baik dan loyalitas. Betapa pentingnya SDM yang prouktif dan berkualitas untuk menunjang roda kehidupan organisasi, sehingga diperlukan penelitian untuk mengetahui pengaruh gaya kepemimpinan dan motivasi terhadap kinerja pegawai. Penelitian ini mempunyai tujuan untuk mengetahui pengaruh gaya kepemimpinan terhadap kinerja pegawai, untuk mengetahui pengaruh motivasi terhadap kinerja pegawai, serta untuk mengetahui pengaruh gaya kepemimpinan dan motivasi secara bersamaan terhadap kinerja pegawai pada Lembaga Amil Zakat Marhamah Maimanah Kota Bogor. Hasil penelitian ini menunjukkan hasil adanya pengaruh gaya kepemimpinan terhadap kinerja pegawai. Hasil berdasarkan perhitungan yang diperoleh $t$ hitung untuk variabel gaya kepemimpinan sebesar 2,101 dengan tingkat signifikansi sebesar 0,047. Karena tingkat signifikansi lebih kecil dari 0,05, maka gaya kepemimpinan berpengaruh positif dan signifikan terhadap kinerja pegawai. Maka disimpulkan bahwa h1 diterima dan h0 ditolak. Adanya pengaruh motivasi terhadap kinerja pegawai. Dari hasil perhitungan yang diperoleh $t$ hitung untuk variabel motivasi sebesar 3,784>1,717 dengan tingkat signifikansi sebesar 0,001. Karena tingkat signifikansi lebih kecil dari 0,05 berarti motivasi berpengaruh positif dan signifikan terhadap kinerja pegawai. Jadi dapat disimpulkan bahwa h1 diterima dan h0 ditolak. Adanya pengaruh gaya kepemimpinan dan motivasi secara bersama-sama terhadap kinerja pegawai. Hasil perhitungan uji R2 menunjukkan bahwa koefisien determinasi (R2) yang diperoleh sebesar 0,395. Hal ini berarti 39,5\% kinerja pegawai dapat dijelaskan oleh variabel gaya kepemimpinan, dan motivasi kerja. Sedangkan sisanya sebesar 60,5\% (100\%-39,5\%), kinerja pegawai dijelaskan oleh variabel lain yang tidak dijelaskan dalam penelitian ini.

Kata Kunci : kepemimpinan, motivasi, kinerja. 


\section{PENDAHULUAN}

Manusia sebagai pusat kegiatan baik itu di dalam masyarakat luas maupun organisasi atau perusahaan dan khususnya dalam organisasi merupakan sumber daya yang sangat menentukan untuk berjalannya organisasi dibandingkan dengan mesin atau perangkat apapun yang ada dalamnya (Masyhudzulhak, 2012:2).

Setiap perusahaan, lembaga atau organisasi sangat memerlukan dukungan sumber daya manusia yang memiliki motivasi kerja yang tinggi, dengan dukungan ini kinerja perusahaan akan terbangun dengan sempurna (Jurnal Edukasi Islami, Vol. 5 No. 09:1231-1250). Motivasi kerja dalam arti dukungan, keinginan, dan daya yang akan mengarahkan perilaku seseorang untuk melakukan suatu pekerjaan. (Winardi, 2011: 2)

Dalam pencapaian tujuan sebuah perusahaan atau organisasi banyak unsur penting dalam pemenuhannya, di antaranya adalah kepemimpinan atau pemimpin. Sumber daya yang telah ada jika tidak dikelola dengan baik maka tidak akan mengantarkan pada tujuan yang telah direncanakan, sehingga peran pemimpin begitu penting dalam memanfaatkan wewenang dan kepemimpinannya untuk mencapai satu tujuan. Pemimpin yang baik dan berkualitas merupakan aset berharga yang sangat menentukan bagi kemajuan peruhasaan atau organisasi yang telah menentukan visi dan misi tertentu sebagai pijakan kesuksesan perusahaan atau organisasi dimasa yang akan datang.

Kinerja suatu perusahaan atau organisasi, baik non profit dan terlebih lagi lembaga profit tidak mungkin akan mencapai titik hasil yang optimal tanpa adanya motivasi dari pemimpin peruhasaan atau organisasi yang bersangkutan. Menurut Wibowo, (2011:80), Kepemimpinan dan gaya kepemimpinan dalam organisasi sangat berperan dalam mempengaruhi kinerja karyawan.

Selain gaya kepemimpinan yang ditujukan seorang pemimpin untuk memberikan arahan pada bawahan, hal penting lain yang harus dipahami juga bahwa mengatur karyawan adalah hal yang rumit dan kompleks, karena mereka memiliki latar belakang yang heterogen yang dibawa ke dalam organisasi atau lembaga. Selain pemimpin, karyawan pun merupakan 
aset penting dan berharga bagi sebuah perusahaan. Sehingga tujuan tidak mungkin akan terwujud bila mereka tidak berperan aktif di dalamnya walaupun perusahaan itu telah dilengkapi dengan berbagai mesin canggih.

Banyak faktor yang mempunyai pengaruh terhadap kinerja karyawan, salah satunya adalah motivasi. Dengan memberikan motivasi yang tepat maka akan mendorong peningkatan kinerja yang lebih baik dan akhirnya akan sangat tujuan perusahaan akan mudah dicapai. Faktor-faktor yang mempengaruhi motivasi seseorang adalah dengan melakukan hal yang penting, apresiasi secara penuh, perasaan memiliki sesuatu, keamanan kerja, upah yang layak, adanya promosi dan karir dalam perusahaan atau organisasi, kondisi kerja yang baik, dan loyalitas. (Jurnal Edukasi Islam, Vol. 4 No.07:787-805).

Dari paparan dan uraian di atas maka terlihat betapa pentingnya SDM yang produktif dan berkualitas untuk menunjang roda kehidupan perusahaan atau organisasi, sehingga diperlukan penelitian untuk mengetahui pengaruh gaya kepemimpinan dan motivasi terhadap pegawai kinerja pegawai.

Dengan memperhatikan latar belakang penelitian di atas, maka dapat diidentifikasi masalah dalam penelitian ini yaitu gaya kepemimpinan, motivas, dan kinerja pegawai.

Berdasarkan identifikasi masalah tersebut di atas, maka perumusan masalah penelitian ini adalah: 1) Adakah pengaruh gaya kepemimpinan terhadap kinerja pegawai Lembaga Amil Zakat Marhamah Maimanah Kota Bogor?; 2) Adakah pengaruh motivasi terhadap kinerja pegawai Lembaga Amil Zakat Marhamah Maimanah Kota Bogor?; 3) Adakah pengaruh gaya kepemimpinan dan motivasi secara bersamaan terhadap kinerja pegawai Lembaga Amil Zakat Marhamah Maimanah Kota Bogor?

Mengacu pada identifikasi masalah di atas, maka penelitian ini mempunyai tujuan sebagai berrikut: 1) Untuk mengetahui pengaruh gaya kepemimpinan terhadap kinerja pegawai Lembaga Amil Zakat Marhamah Maimanah Kota Bogor; 2) Untuk mengetahui pengaruh motivasi terhadap kinerja pegawai Lembaga Amil Zakat Marhamah Maimanah Kota Bogor; dan 3) Untuk mengetahui pengaruh gaya kepemimpinan dan motivasi secara bersamaan terhadap kinerja pegawai Lembaga Amil Zakat Marhamah Maimanah Kota Bogor. 


\section{TINJAUAN TEORITIS}

\section{Pemimpin dan Kepemimpinan}

Menurut Hafidhuddin dan Tanjung (2003: 120), ada beberapa kriteria pemimpin yang sukses dalam sebuah organisasi. (I), ketika seorang pemimpin dicintai oleh bawahannya. Organisasi yang dipimpinya akan berjalan dengan baik jika kepemimpinannya dinahkodai oleh pemimpin yang dicintai oleh bawahan. Kriteria (II) adalah pemimpin yang mampu menampung aspirasi bawahannya. Selain dicintai, pemimpin yang baik juga dapat menerima kritik dari bawahannya. Kriteria (III) adalah pemimpin yang selalu bermusywarah. Seorang pemimpin selain harus siap menerima kritikan, pemimpin yang sukses juga selalu bermusyawarah. Musyawarah dilakukan dengan orang-orang tertentu untuk membahas persoalanpersoalan yang berkaitan dengan kebijakan-kebijakan pubik, atau yang bersangkutan dengan kepentingan umum dari perusahaan. Kriteria ke (IV) adalah tegas, namun tidak otoriter melainkan tegas dan bermusyawarah serta dicintai, walaupun perusahaan yang dipimpinnya bergerak dalam bidang ekonomi.

Gambar 1. Empat kriteria pemimpin sukses

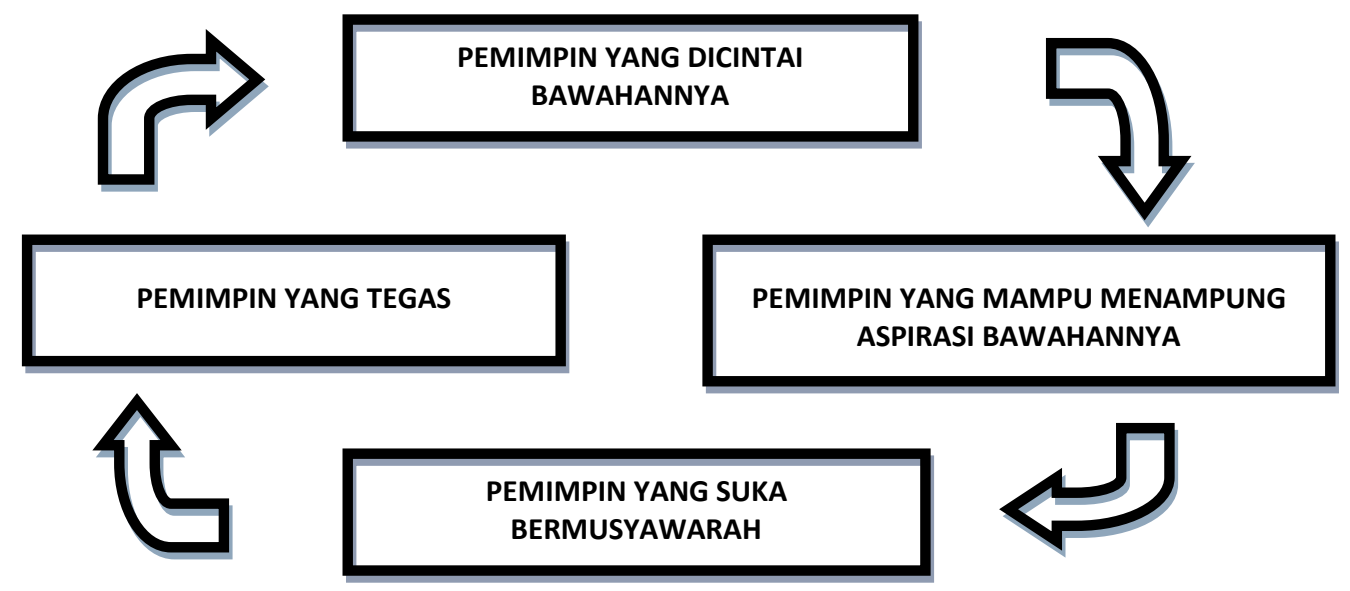

\section{Gaya Kepemimpinan}

Dalam melaksanakan fungsi-fungsi kepemimpinan, maka akan berlangsung aktivitas kepemimpinan. Apabila aktivitas tersebut dipilah-pilah, maka akan terlihat gaya kepemimpinan dengan polanya masing-masing. Gaya kepemimpinan tersebut merupakan dasar dalam mengklasifikasikan tipe kepemimpinan. Gaya kepemimpinan memiliki tiga pola dasar, yaitu: 1) 
Gaya kepemimpinan yang berpola pada kepentingan pelaksanaan tugas; 2) Gaya kepemimpinan yang berpola pada pelaksanaan hubungan kerjasama; dan 3) Gaya kepemimpinan yang berpola pada kepentingan hasil yang dicapai.

Berdasarkan pada tiga pola dasar tersebut maka akan terbentuk perilaku kepemimpinan yang berwujud pada kategori kepemimpinan yang terdiri dari tiga tipe pokok kepemimpinan, yaitu: 1) Tipe kepemimpinan otoriter; 2) Tipe kepemimpinan kendali bebas; dan 3) Tipe pemimpin demokratis.

Ketiga kepemimpinan di atas dalam prakteknya saling mengisi atau saling menunjang secara bervariasi, yang disesuaikan dengan situasinya sehingga akan menghasilkan kepemimpinan yang efektif. Pola di atas dapat dijelaskan pada tabel berikut ini.

Tabel 1. Tipe Kepemimpinan

\begin{tabular}{|c|c|}
\hline Gaya Kepemimpinan & Pendekatan \\
\hline Otoriter & Kekuasaan pada Pemimpin \\
\hline Kendali Bebas & Kekuasaan pada bawahan \\
\hline Demokratis & Kekuasaan pada bawahan \\
\hline
\end{tabular}

Tabel 2. Tipe Kepemimpinan

\begin{tabular}{|c|c|c|}
\hline Otoriter & Demoktatis & Kendali Bebas \\
\hline $\begin{array}{l}\text { Semua policy dilakukan } \\
\text { oleh pemimpin. }\end{array}$ & $\begin{array}{l}\text { Semua policies } \\
\text { merupakan pembahasan } \\
\text { kelompok dan keputusan } \\
\text { kelompok yang } \\
\text { dirangsang dan dibantu } \\
\text { oleh pemimpin }\end{array}$ & $\begin{array}{l}\text { Kebebasan lengkap untuk } \\
\text { keputusan kelompok atau } \\
\text { individual dengan } \\
\text { minimum partisipasi } \\
\text { pemimpin }\end{array}$ \\
\hline $\begin{array}{l}\text { Teknik-teknik dari } \\
\text { langkah-langkah aktivitas } \\
\text { ditentukan oleh pejabat } \\
\text { satu persatu, hingga } \\
\text { langkah-langkah } \\
\text { mendatang senantiasa } \\
\text { tidak pasti }\end{array}$ & $\begin{array}{l}\text { Perspektif aktivitas dicapai } \\
\text { selama diskusi } \\
\text { berlangsung. Dilukiskan } \\
\text { langkah-langkah umum ke } \\
\text { arah tujuan kelompok dan } \\
\text { apabila diperlukan nasihat } \\
\text { teknis, maka pemimpin } \\
\text { menyarankan dua atau } \\
\text { lebih banyak prosedur- } \\
\text { prosedur alternatif yang } \\
\text { dapat dipilih. }\end{array}$ & $\begin{array}{l}\text { Macam-macam bahan } \\
\text { disediakan oleh } \\
\text { pemimpin, yang dengan } \\
\text { jelas mengatakan bahwa } \\
\text { ia akan menyediakan } \\
\text { keterangan apabila ada } \\
\text { permintaan. la tidak turut } \\
\text { mengambil bagian dalam } \\
\text { diskusi kelompok. }\end{array}$ \\
\hline $\begin{array}{l}\text { Pemimpin biasanya } \\
\text { mendikte tugas pekerjaan } \\
\text { khusus dan teman sekerja }\end{array}$ & $\begin{array}{l}\text { Para anggota bebas untuk } \\
\text { bekrja dengan siapa yang } \\
\text { mereka kehendaki dan }\end{array}$ & $\begin{array}{l}\text { Pemimpin tidak berpartisi- } \\
\text { pasi sama sekali }\end{array}$ \\
\hline
\end{tabular}




\begin{tabular}{|c|c|c|}
\hline setiap anggota & $\begin{array}{l}\text { pembagian tugas terserah } \\
\text { pada kelompok }\end{array}$ & \\
\hline $\begin{array}{l}\text { Dominator cenderung } \\
\text { bersikap pribadi dalam } \\
\text { pujian dan kritik pekerjaan } \\
\text { setiap anggota, ia tiak } \\
\text { turut serta dalam } \\
\text { partisipas kelompok } \\
\text { secara aktif kecuali } \\
\text { apabila ia memberikan } \\
\text { demonstrasi }\end{array}$ & $\begin{array}{l}\text { Pemimpin bersifat objektif } \\
\text { dalam pujian dan kritiknya } \\
\text { dan ia berusaha untuk } \\
\text { menjadi anggota } \\
\text { kelompok secara mental, } \\
\text { tanpa terlampau banyak } \\
\text { melakukan pekerjaan } \\
\text { tersebut }\end{array}$ & $\begin{array}{l}\text { Komentar spontan yang } \\
\text { tidak frekuensi atas } \\
\text { aktivitas-aktivitas anggota } \\
\text { dan ia tidak berusaha } \\
\text { sama sekali untuk menilai } \\
\text { atau mengatur kejaian- } \\
\text { kejadian }\end{array}$ \\
\hline
\end{tabular}

\section{Motivasi}

Istilah motivasi (motivation) berasal dari bahasa laitn, yaitu movere, yang berarti "menggerakkan" (to move). Winardi, (2011: 1). Menurut (Kamus) Lengkap Bahasa Indonesia Modern Karya Muhammad Ali, (Motif) diartikan: sebab-sebab yang menjadi dorongan tindakan seseorang; dasar pikiran dan pendapat; sesuatu yang menjadi pokok. Sehingga dari pengertian motif tersebut, dapat diturunkan pengertian motivasi sebagai sesuatu yang pokok yang menjadi dorongan seseorang untuk bekerja. Arep,Tanjung (2003: 217). Cascio (1995), dalam Raharjo (2013: 154) Menyatakan motivasi sebagai kekuatan yang dihasilkan dari keinginan untuk memenuhi kebutuhan. Motivasi berkaitan dengan tingkat usaha yang dilakukan oleh seseorang dalam rangka mengejar suatu tujuan.

Sedangkan motivasi kerja adalah sesuatu yang menimbulkan dorongan atau semangat kerja atau pendorong semangat kerja. Menurut Bachrun (2011: 129), motivasi yang rendah dipastikan akan menyebabkan produktivitas menjadi rendah pula sehingga kinerja menjadi menurun. Karyawan yang motivasinya kurang akan menampilkan rasa tidak senang akan tugas-tugas dan tujuannya serta cenderung masa bodoh. Akibatnya, kinerja mereka menjadi buruk dan sering melepaskan tanggung jawabnya.

\section{Unsur-unsur Motivasi}

Stanly Vance (1982) dalam Danim (2004:15), menyatakan bahwa pada hakikatnya motivasi adalah perasaan atau keinginan seseorang yang berada dan bekerja pada kondisi tertentu untuk melaksanakan tindakantindakan yang menguntungkan dilihat dari perspektif pribadi dan terutama organisasi. 
Menurut Danim (2004:15), motivasi merupakan kekuatan yang muncul dari dalam diri inividu untuk mencapai tujuan atau keuntungan tertentu di lingkungan dunia kerja atau di pelataran kehidupan pada umumnya. Dengan demikian, motivasi mengandung beberapa unsur, yaitu: 1) Tujuan; 2) Kekuatan dari dalam diri individu; dan 3) Keuntungan.

\section{Kinerja}

Kata "kinerja" merupakan terjemahan dari kata performance, yang secara umum diartikan sebagai cara-cara dan hasil yang telah dicapai seseorang atau kelompok atau organisasi dalam melaksanakan pekerjaannya. Istilah kinerja berasal dari kata job performance atau actual performance (pretasi kerja atau pretasi sesungguhnya yang dicapai oleh seseorang). Pengertian kinerja adalah hasil kerja secara kualitas dan kuantitas yang dicapai oleh seorang pegawai dalam melaksanakan tugasnya sesuai dengan tanggung jawab yang diberikan padanaya (Mangkunegara, 2001) dalam Masyhudzulhak ( 2012:102).

Gambar 2. Dimensi kerja

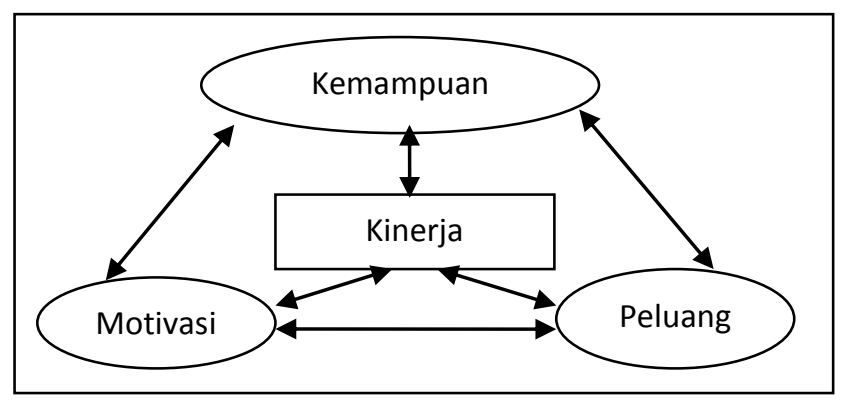

\section{Faktor-faktor yang mempengaruhi kinerja}

Faktor yang mendorong kinerja adalah perilaku. Perilaku adalah tentang bagaimana seorang karyawan bertindak ( how you act), dan bukan tentang apa dan siapa (what you are or who you are ). Terdapat beberapa faktor yang perlu diperhatikan untuk suatu organisasi agar mempunyai kinerja yang baik, yaitu menyangkut peryataan tentang maksud dan nilai-nilai manajemen strategis, manajemen sumber daya manusia, pengembangan organisasi, konteks organisasi, desain kerja, fungsionalisasi, budaya dan kerja sama: 1) Peryataan tentang maksud dan nilai-nilai; 2) Manajemen strategis; 3) Manajemen sumber daya manusia; 4) Pengembangan 
organisasi; 5) Konteks organisasi; 6) Desain kerja; 7) Fungsionalisasi; 8) Budaya; dan 8) Kerjasama.

\section{Aspek-aspek yang dinilai dalam kinerja}

Menurut Raharjo (2013: 95), penilaian kinerja sebagai kegiatan evaluasi terhadap kesetiaan, kejujuran, kepemimpinan, kerjasama, loyalitas, dedikasi, dan partisipasi sebagai kontribusi keseluruhan yang diberikan oleh setiap individu bagi organisasinya. Aspek-aspek yang dinilai dalam kinerja menurut Rivai (2008: 324), dapat dikelompokan menjadi: 1) Kemampuan teknis, yaitu kemampuan menggunakan pengetahuan, teknik dan peralatan yang digunakan untuk melaksanakan tugas serta pengalaman dan pelatihan yang diperolehnya; 2) Kemampuan konseptual, yaitu kemampuan untuk memahami kompleksitas perusahaan dan penyesuaian bidang gerak dari unit masing-masing kedalam bidang operasional perusahaan secara menyeluruh, yang pada intinya individual tersebut memahami tugas, fungsi serta tanggung jawabnya sebagai seorang karyawan.

Agar tetap eksis serta siap dan mampu bersaing dengan Lembaga Zakat yang lain, maka LAZ MM membutuhkan kinerja yang tinggi dari semua pegawainya. Pencapaian tingkat kinerja seorang pegawai berkaitan erat dengan beberapa faktor, antara lain gaya kepemimpinan dan motivasi. Apabila seorang pegawai memiliki motivasi tinggi terhadap tugas dan tanggung jawabnya, maka pegawai tersebut akan semakin matang dan akan lebih mengetahui dan mendalami segala hal yang berkaitan dengan pekerjaannya. Dan ini berarti pegawai tersebut tidak lagi mengalami kendala dalam menjalankan tuga dan tanggung jawabnya.

Dalam rangka usulan pengaruh gaya kepemimpinan dan motivasi terhadap kinerja pegawai Lembaga Amil Zakat Marhamah Maimanah Bogor, dapat digambarkan konstelasi antar variabel bebas berpengaruh positif terhadap variabel terikat. Adapun kerangka berpikir penelitian yang digambarkan antara variable bebas dan terkait yang diajukan penulis sebagai berikut: 1) Pengaruh gaya kepemimpinan $\left(X_{1}\right)$ dengan kinerja karyawan (Y), Gaya kepemimpinan merupakan norma perilaku yang digunakan oleh seseorang pada saat orang tersebut mencoba mempengaruhi perilaku orang lain. Sedangkan kinerja adalah hasil kerja 
secara kualitas dan kuantitas yang dicapai oleh seorang pegawai dalam melaksanakan tugasnya sesuai dengan tanggung jawab yang diberikan padanya; 2) Pengaruh motivasi $\left(\mathrm{X}_{2}\right)$ dengan kinerja $(\mathrm{Y})$ mendorong pegawai menjadi lebih baik sehingga diharapkan pegawai mau bekerja dengan penuh tanggung jawab dan lebih baik lagi, bila hal itu terwujud maka akan timbul kepercayaan dan akan mendorong seseorang memiliki kinerja yang lebih berkualitas lagi; 3) Pengaruh gaya kepemimpinan $\left(X_{1}\right)$, motivasi $\left(X_{2}\right)$ secara bersama-sama berperngaruh pada kinerja $(\mathrm{Y})$, untuk faktor-faktor lainnya yang mempengaruhi $Y$ tidak diteliti atau dianalisa lebih lanjut. Gambar dari kerangka berpikir penelitian ini dapat dilihat pada gambar 6 di bawah ini:

Gambar 3. Metode penelitian

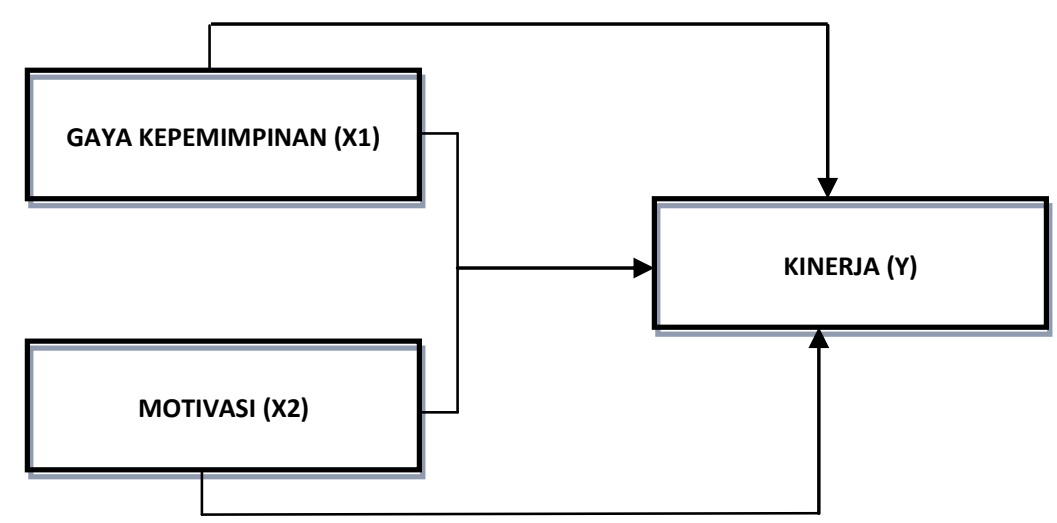

\section{METODOLOGI}

Tempat yang dipilih untuk melakukan penelitian berkaitan dengan permasalahan yang diajukan, adalah Lembaga Amil Zakat Marhamah Maimanah (LAZ MM). Tempat penelitian berlokasi di Jl. Sancang No. 2 B, Kelurahan Babakan, Kecamatan Bogor Tengah, Kota Bogor 16128 Jawa Barat. No.Telp. (0251) 4777123, Mobile Phone: 082114654000 dengan alamat website://www.lazmm.org dan alamat Email : layanandonatur@lazmm.org

Metode yang digunakan dalam penelitian ini adalah metode deskriptif analisis dan metode asosiatif/hubungan. Menurut Nazir (2003:54) mengemukakan metode deskriptif adalah: "suatu metode dalam meneliti status sekelompok manusia, suatu objek, suatu set kondisi, suatu sistem pemikiran, ataupun suatu kelas peristiwa pada masa sekarang". 
Disamping menggunakan metode deskriptif, pada penelitian ini digunakan metode asosiatif/hubungan. Menurut Sugiyono (2008) penelitian asosiatif merupakan "penelitian yang bertujuan untuk mengetahui hubungan antara dua variabel atau lebih". Dengan penelitian ini maka akan dapat dibangun suatu teori yang dapat berfungsi untuk menjelaskan, meramalkan dan mengontrol suatu gejala.

Dalam penelitian ini, penulis akan menggunakan studi populasi yaitu berupa keseluruhan subyek yang termasuk dalam penelitian ini, yakni seluruh karyawan LAZ MM. Arikunto (2010:173) mengatakan bahwa populasi adalah keseluruhan subjek penelitian. Apabila seseorang ingin meneliti semua elemen yang ada dalam wilayah penelitian, maka penelitiannya merupakan penelitian populasi. Studi atau penelitiannya juga disebut studi populasi atau studi sensus. Sedangkan yang dimaksud sampel adalah bagian yang terdapat atau terwakili dari populasi. Arikunto (2010: h. 174) mengatakan bahwa sampel adalah sebagian atau wakil populasi yang diteliti. Dinamakan penelitian sampel apabila kita bermaksud untuk menggeneralisirkan hasil penelitian sampel.

Tabel 3

Komposisi Pengurus LAZ MM Kota Bogor

\begin{tabular}{|c|c|c|}
\hline No & Nama & Jumlah \\
\hline 1. & Ketua LAZ MM & 1 orang \\
\hline 2. & Sekretaris LAZ MM & 1 orang \\
\hline 3. & Bendahara LAZ MM & 1 orang \\
\hline 4. & Divisi Wakaf Tunai & 1 orang \\
\hline 5 & Divisi Humas & 1 orang \\
\hline 6. & Divisi Telemarketing & 1 orang \\
\hline 7. & Divisi Fundraising & 1 orang \\
\hline
\end{tabular}

Teknik sampling yang akan digunakan dalam penelitian ini adalah teknik probability sampling. Menurut Maksudi (2005:93), pengambilan sampel probabilitas adalah "cara yang digunakan untuk pengambilan sampel, apabila setiap unsur yang terdapat di dalam populasinya mempunyai kesempatan (probabilitas) yang sama untuk terpilih sebagai sampel." 


\section{Variabel Penelitian}

Variabel dalam penelitian ini terdiri dari variabel bebas $(X)$ dan variabel terikat $(\mathrm{Y})$ yang dikategorikan sebagai berikut :

$\begin{array}{ll}\text { Variabel bebas }(\mathrm{X} 1) & =\text { Gaya kepemimpinan } \\ \text { Variabel bebas }(\mathrm{X} 2) & =\text { Motivasi } \\ \text { Variabel terikat }(\mathrm{Y}) & =\text { Kinerja }\end{array}$

Tabel 4

Operasional Variabel Gaya Kepemimpinan, Motivasi terhadap kinerja LAZ MM

\begin{tabular}{|c|c|c|c|c|}
\hline No & Variabel & Dimensi & Indikator & Skala \\
\hline 1. & $\begin{array}{c}\text { Gaya } \\
\text { Kepemimpinan } \\
(\mathrm{X} 1)\end{array}$ & $\begin{array}{l}\text { 1. Kemampuan } \\
\text { Memimpin } \\
\text { (Musa } \\
\text { Hubeis,2007) } \\
\\
\\
\text { 2. Hubungan } \\
\text { atasa. dan } \\
\text { bawahan } \\
\text { (Kartini Karton, } \\
\text { 1997) }\end{array}$ & $\begin{array}{l}\text { 1. Kemampuan dalam } \\
\text { mengambil } \\
\text { keputusan } \\
\text { 2. Kebijaksanaan } \\
\text { 3. Keteladanan } \\
\text { 4. Kerendahan hati } \\
\text { 1. Partisipatif } \\
\text { 2. Tingkat loyalitas } \\
\text { 3. Tidak mementingkan } \\
\text { diri sendiri }\end{array}$ & $\begin{array}{c}\text { Ordinal } \\
(1-5)\end{array}$ \\
\hline 2. & $\begin{array}{c}\text { Motivasi } \\
\text { (Sondang P } \\
\text { Siagian,2004) } \\
(\mathrm{X} 2)\end{array}$ & $\begin{array}{l}\text { 1. } \begin{array}{l}\text { Suasana } \\
\text { kerja }\end{array} \\
\text { 2. } \begin{array}{l}\text { Perhatian } \\
\text { pemimpin }\end{array} \\
\text { 3. Kesempatan } \\
\text { promosi }\end{array}$ & $\begin{array}{l}\text { 1. Lancarnya } \\
\text { komunikasi } \\
\text { 2. Keadaan Lingkungan } \\
\text { 1. Perhatian } \\
\text { 2. Pujian } \\
\text { 3. Penghargaan } \\
\text { 1. Promosi jabatan } \\
\text { 2. Kesempatan } \\
\text { 3. Partisipasi kerja } \\
\text { 4. Pendidikan dan } \\
\text { pelatihan } \\
\text { 1. Kenaikan gaji } \\
\text { berkala } \\
\text { 2. Bonus bagi pegawai } \\
\text { berprestasi }\end{array}$ & $\begin{array}{c}\text { Ordinal } \\
(1-5)\end{array}$ \\
\hline 3. & $\begin{array}{c}\text { Kinerja } \\
\text { Pegawai } \\
\text { Sukmalana } \\
\text { Soelaiman(200 } \\
\text { 3) } \\
(\mathrm{Y})\end{array}$ & $\begin{array}{l}\text { 1. Pengembang } \\
\text { an diri }\end{array}$ & $\begin{array}{l}\text { 1. Pemahaman tentang } \\
\text { konsep kinerja } \\
\text { 2. Etos kerja yang } \\
\text { dimiliki } \\
\text { 3. Tingkat pemahaman } \\
\text { dan pengertian }\end{array}$ & $\begin{array}{c}\text { Ordinal } \\
(1-5)\end{array}$ \\
\hline & & $\begin{array}{l}\text { 2. Hubungan } \\
\text { Sosial }\end{array}$ & $\begin{array}{l}\text { 1. Tingkat kejujuran } \\
\text { 2. Tingkat inisiatif }\end{array}$ & \\
\hline
\end{tabular}




\begin{tabular}{|l|l|l|l|l|}
\hline No & Variabel & \multicolumn{1}{|c|}{ Dimensi } & \multicolumn{1}{c|}{ Indikator } & Skala \\
\hline & & 3. Hasil & $\begin{array}{l}\text { 1. Produktivitas kerja } \\
\text { 2. Kualitas layanan } \\
\text { 3. Ketelitia }\end{array}$ & \\
& & & & \\
\hline
\end{tabular}

\section{Instrumen Penelitian/Alat Pengumpulan Data}

Dalam melakukan pengumpulan data penelitian ini, penulis menggunakan pengumpulan data berupa studi kepustakaan melalui literatur yang ada dan beragam, serta dengan secara langsung di lapangan yang mencakup unsur-unsur berikut. Kuesioner, ini merupakan alat pengumpulan data utama untuk menggali sumber data faktual dari para responden yang menjadi sampel penelitian sesuai dengan desain dan variable penelitian. Kuesioner (lampiran) diajukan dalam bentuk pernyataan yang tersusun berdasarkan operasional variable, artinya indikator-indikator itulah yang dijadikan instrument untuk mencapai obyek penelitian. Indikator-indikator ini berasal dari penjabaran variabel penelitian menjadi sub variable/dimensi penelitian dan akhirnya menjadi isi atau obyek yang diteliti.

\section{Teknik Analisis Data}

Analisis data adalah merupakan kegiatan mengumpulkan data/fakta, selanjutnya dipelajari dan dianalisis secara sistematis dan teratur, sehingga berdasarkan data/fakta tersebut dapat diperoleh gambaran tentang sesuatu secara jelas. Tahap selanjutnya untuk mencari derajat hubungan digunakan analisis statistik parametrik, yaitu untuk menganalisis data kuantitatif yang didapat dari proses pengambilan data di atas, dan diolah dengan menggunakan teknik analisis statistik yaitu dengan cara mencari koefisien regresi antara variabel bebas $(\mathrm{X})$ dengan variabel terikat $(\mathrm{Y})$. Dalam penelitian ini, yang dimaksud variabel bebas adalah gaya kepemimpinan, motivasi dan variabel terikat adalah kinerja. Untuk jelasnya, dapat digambarkan dalam paradigma penelitian berikut: 
Gambar 4.Konstelasi Variabel Penelitian

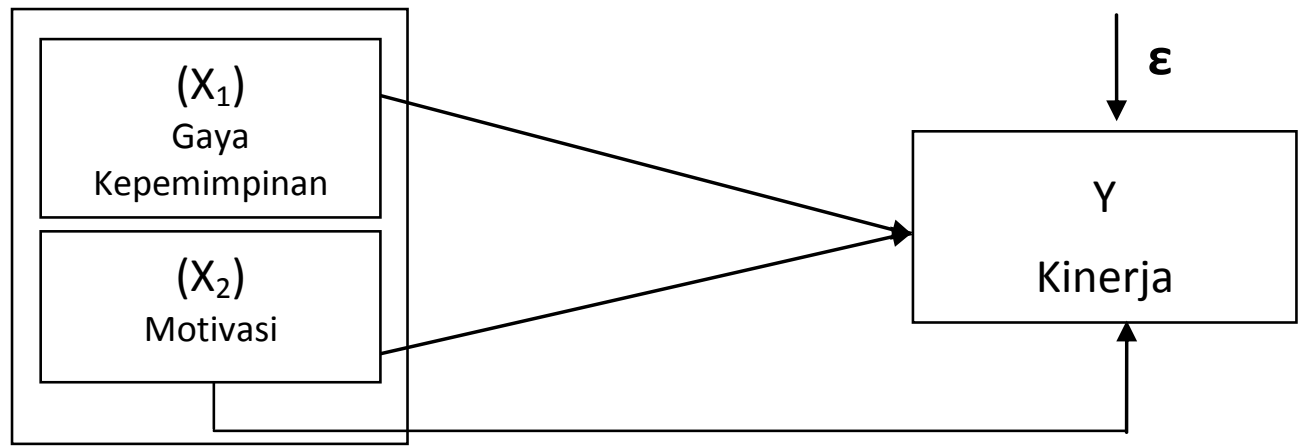

Keterangan:

$\mathrm{X}_{1}=$ Gaya kepemimpinan

$\mathrm{X}_{2}=$ Motivasi

$\mathrm{Y} \quad=$ Kinerja (variabel terikat)

\section{HASIL PENELITIAN}

(LAZ MM) adalah Lembaga Amil Zakat Marhamah Maimanah yang didirikan pada tahun 2002 yang beralamat di Jalan Sancang No. 2B, Kelurahan. Babakan, Kecamatan Bogor Tengah, Kota Bogor, Propinsi Jawa Barat. Lembaga Amil Zakat Marhamah Maimanah (LAZ MM) berlokasi di Jl. Sancang No. 2B Kel. Babakan, Kec. Bogor Tengah, Bogor 16128 Jawa Barat. No.Telp. (0251) 4777123, Mobile Phone: 082114654000 dengan alamat Website : www.lazmm.org dan alamat Email : layanandonatur@lazmm.org

Berdirinya LAZ MM adalah sebagai bentuk kepedulian yang besar terhadap pembangunan masa depan ummat Islam di Indonesia. Untuk mewujudkan harapan besar tersebut LAZ MM memfokuskan diri pada bidang garapan utama yaitu: pendidikan, dakwah, kesehatan, dan pemberdayaan ekonomi ummat yang terangkum dalam program besar dengan tema "Mencetak Generasi Robbani".

Seluruh program donasi yang ditawarkan oleh LAZ MM kepada para muzzaki, muhsinin, dan donatur baik perorangan maupun perusahaan diharapkan menjadi solusi terbesar bagi teratasinya permasalahan ummat yang terjadi di Indonesia. Program membangun generasi cemerlang ini merupakan program yang bersifat langgeng atau kontinyu. Yang dimaksud dengan langgeng atau kontinyu adalah bahwa program tersebut bersifat 
melembaga, tersistem dan mudah diakses oleh setiap dhuafa di mana saja mereka berada.

Gambar 5. Struktur Organisasi

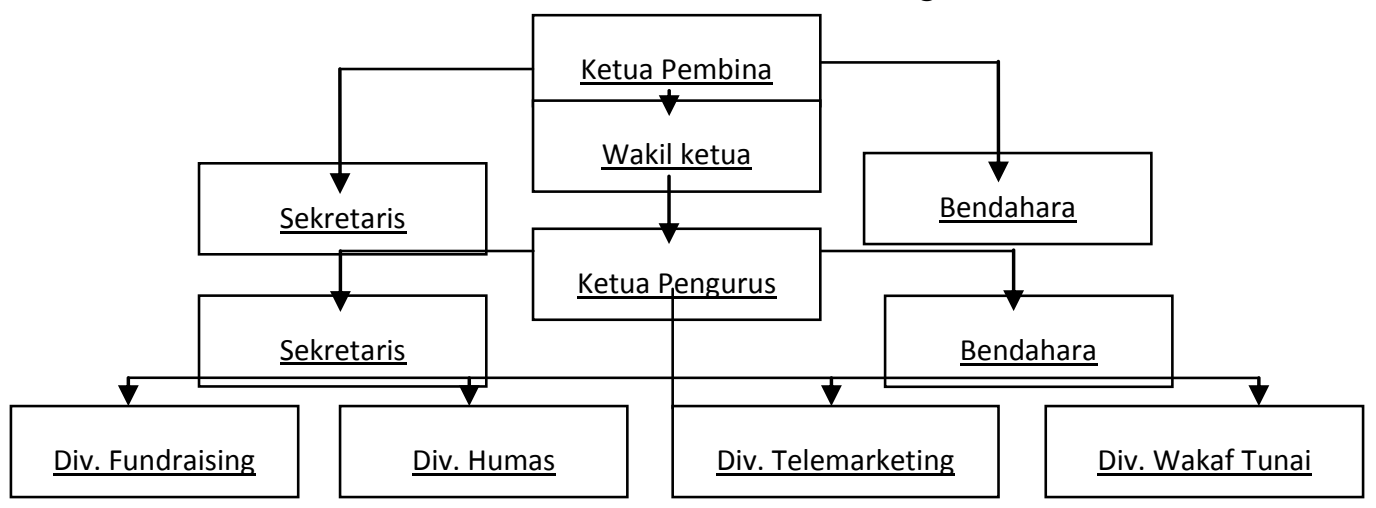

LAZ MM adalah sebuah lembaga sosial yang berusaha mengkoordinir potensi besar kaum muslimin melalui zakat, wakaf, infak dan shodaqoh yang kemudian disalurkan kepada orang-orang yang berhak menerimanya. Visi lembaga ini yaitu; "Menjadi lembaga amil zakat yang visioner dan amanah dalam mencetak generasi robbani di Indonesia pada tahun 2017.Adapun misinya adalah; "Mengoptimalkan potensi umat melalui zakat, infak, shodaqoh dan dana sosial lainnya.

Untuk mewujudkan harapan besar tersebut LAZ MM memfokuskan diri pada bidang garapan utama yaitu: pendidikan, dakwah, kesehatan, dan pemberdayaan ekonomi ummat yang terangkum dalam program besar dengan tema "Mencetak Generasi Robbani”.

\section{ANALISIS DAN PEMBAHASAN}

\section{Analisis Penelitian}

Pengujian validitas instrumen penelitian dilakukan dengan tujuan mengetahui keabsahan (validitas) setiap item kuesioner. Pengertian valid adalah kuesioner dinilai efektif untuk menggali permasalahan yang dijadikan obyek penelitian, dengan kata lain instrumen yang digunakan memang mengukur apa yang seharusnya diukur. Pengujian validitas instrumen penelitian dilakukan dengan rumus koefisien Pearson product moment.

Pengujian validitas dilakukan dengan membandingkan angka korelasi pada product moment dengan angka kritis rtabel. Nilai rtabel pada tingkat kepercayaan $5 \%$ df $=(24-2)=22$ adalah 0,343. Jika angka korelasi produk momen lebih besar dari angka tabel maka, item tersebut adalah valid. Nilai 
korelasi validitas tersebut didapatkan melalui hitungan program Statistical Package for Social Science (SPSS) 19.0 for windows berikut :

Validitas instrumen penelitian didasarkan kriteria, jika $r$ hitung $\leq$ rtabel berarti tidak valid dan $r$ hitung $\geq$ rtabel berarti valid. Uji validitas dilakukan untuk mengukur sah, atau tidaknya indikator, atau kuesioner dari masingmasing variabel. Pengujian dilakukan dengan membandingkan rhitung dan $r$ tabel. Nilai $r$ hitung merupakan hasil korelasi jawaban responden pada masing-masing pertanyaan di setiap variabel yang dianalisis dengan bantuan program SPSS Ver 19.0 dan output bernama corrected item correlation.

Tabel.5

Uji Validitas Instrumen

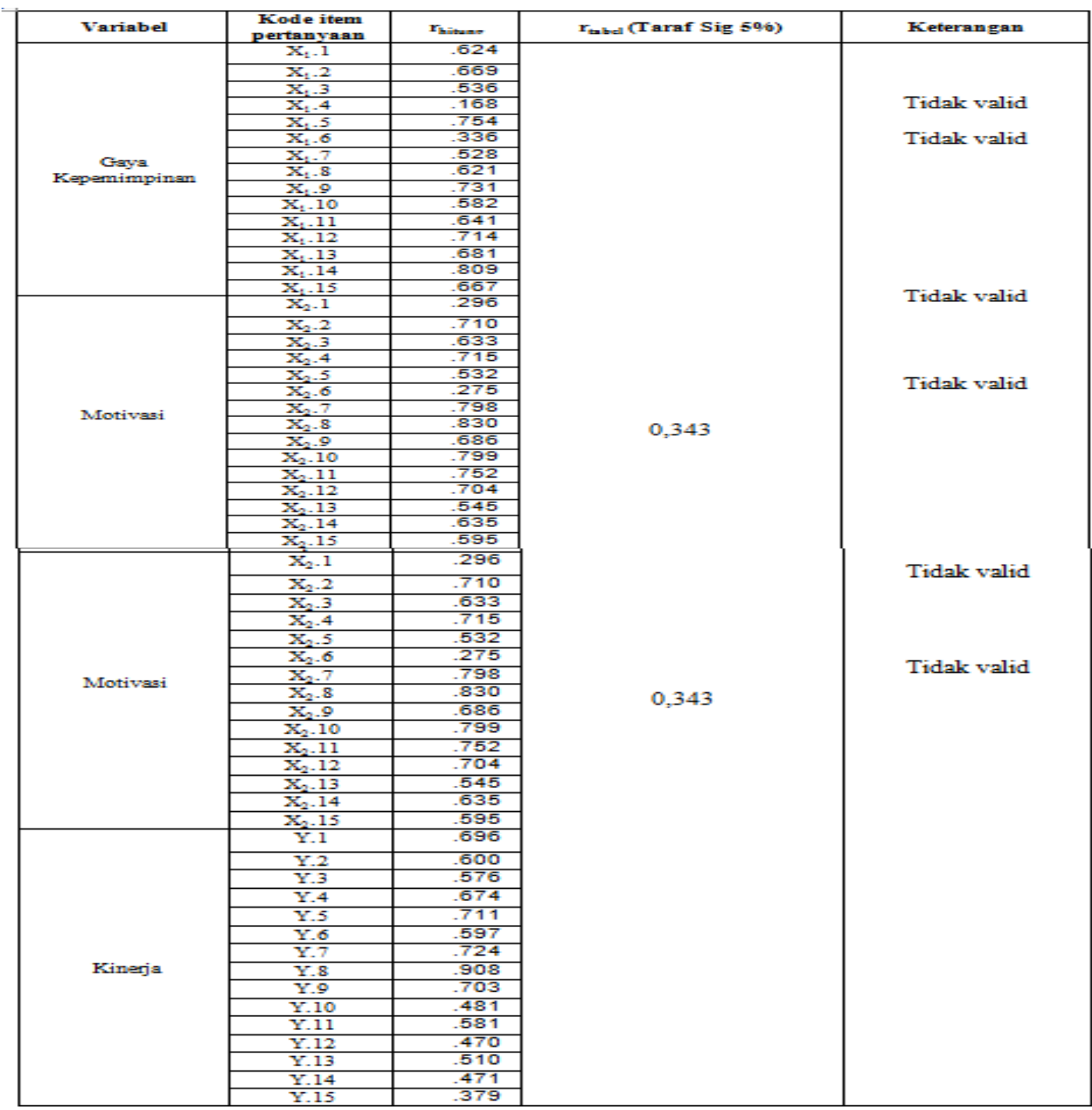

Dari hasil uji validitas pada Tabel 7 , terlihat bahwa $r$ hitung setiap indikator variabel gaya kepemimpinan, motivasi lebih besar dibandingkan 
dengan nilai $r$ tabel, maka indikator, atau kuesioner yang digunakan oleh masing-masing variabel dinyatakan valid untuk digunakan sebagai alat ukur variabel.

\section{Pengujian Reliabilitas}

Pengujian reliabilitas alat ukur dimaksudkan untuk mengetahui ketepatan nilai instrumen yang digunakan untuk mengumpulkan data primer dari sampel penelitian ternyata reliabel atau tidak reliabel dalam mengukur variabel penelitian.

Pengertian reliabel adalah bahwa alat ukur yang digunakan dalam penelitian dapat diandalkan, karena dalam situasi yang berbeda kuesioner penelitian tidak menimbulkan persepsi jauh berbeda. Reliabilitas suatu indikator, atau kuesioner dapat dilihat dari nilai alpha cronbach's, yaitu apabila nilai alpha cronbach's lebih besar (>) 0,60, maka indikator, atau kuesioner adalah reliabel, sedangkan nilai alpha cronbach's $<0,60$; maka indikator kuesioner tidak reliabel. Secara keseluruhan hasil uji reliabilitas per item pertanyaan tersaji pada Tabel 8 .

Pengujian reliabilitas menggunakan teknik reliability analysis alpha dengan program SPSS 19.0 for windows dan hasil pengujiannya sebagai berikut:

Tabel .6

Uji Reliabilitas Item Instrumen

\begin{tabular}{|c|c|c|}
\hline Variabel & Koefisien Alpha & \multirow{2}{*}{ Keputusan } \\
\hline Gaya Kepemimpinan $\left(\mathrm{X}_{1}\right)$ & 0,912 & \\
\hline Motivasi $\left(\mathrm{X}_{2}\right)$ & 0,908 & \\
\hline Kinerja $(\mathrm{Y})$ & 0,906 & \\
\hline
\end{tabular}

$\checkmark$ Koefisien reliabilitas alpha untuk variabel Gaya Kepemimpinan (X1) yang diperoleh adalah 0,912

$\checkmark$ Koefisien reliabilitas alpha untuk variabel Motivasi (X2) yang diperoleh adalah 0,908

$\checkmark$ Koefisien reliabilitas alpha untuk variabel Kinerja (Y) yang diperoleh adalah 0,906 
Dari Tabel 8 terlihat, bahwa variabel secara keseluruhan nilai alpha cronbach's > 0,60, sehingga dapat disimpulkan bahwa indikator yang digunakan untuk variabel gaya kepemimpinan dan motivasi terhadap kinerja dinyatakan handal, atau dapat dipercaya sebagai alat ukur variabel.

\section{Uji Normalitas Data}

Uji normalitas digunakan untuk melihat normalitas model regresi. Pengujian dilakukan dengan menggunakan grafik, yaitu histogram dan normal P-P Plot Regression.

\section{Kurva Histogram}

Pada kurva histogram, model memenuhi asumsi normalitas jika bentuk kurva simetris atau tidak melenceng ke kiri maupun ke kanan. Hasil uji normalitas dilakukan dengan histogram.

a. Histogram Gaya Kepemimpinan (X1) terhadap Kinerja (Y)

Histogram untuk pengujian normalitas regresi linear antara gaya kepemimpinan terhadap kinerja dapat dilihat pada Gambar 10.

Gambar.10 Kurva Histogram Gaya Kepemimpinan (X1) terhadap Kinerja $(\mathrm{Y})$

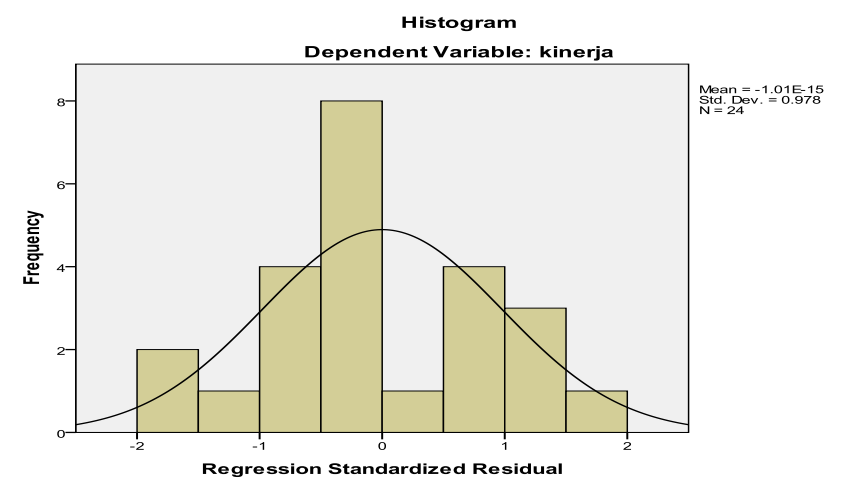

Dari gambar di atas terlihat bahwa bentuk kurva simetris dan tidak melenceng ke kiri, maupun ke kanan, sehingga dikatakan histogram model regresi berdistribusi normal.

b. Histogram Motivasi (X2) terhadap Kinerja ( $Y$ )

Gambar.11 Kurva Histogram Motivasi (X2) terhadap Kinerja (Y) 


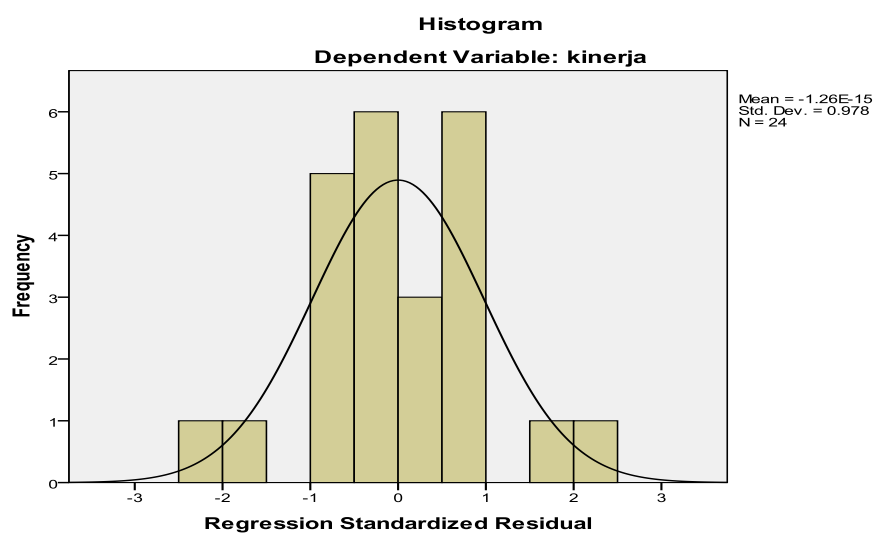

Histogram untuk pengujian normalitas regresi linear antara motivasi terhadap kinerja.

Dari gambar di atas terlihat bahwa bentuk kurva simetris dan tidak melenceng ke kiri maupun ke kanan, sehingga berdasarkan kurva histogram model regresi berdistribusi normal.

\section{Normal P-P Plot}

Pada normal p-p plot, model memenuhi asumsi normalitas jika titik-titik pada kurva berhimpit mengikuti garis diagonalnya. Berikut ini hasil uji normalitas dengan grafik normal $p-p$ plot.

\section{Kurva normal P-P Plot Gaya Kepemimpinan (X1) terhadap Kinerja (Y)}

Kurva normal p-p plot untuk pengujian normalitas regresi linear antara gaya kepemimpinan terhadap kinerja dapat dilihat pada Gambar 12.

Gambar.12 Kurva P-P Plot Gaya Kepemimpinan (X1) terhadap Kinerja (Y)

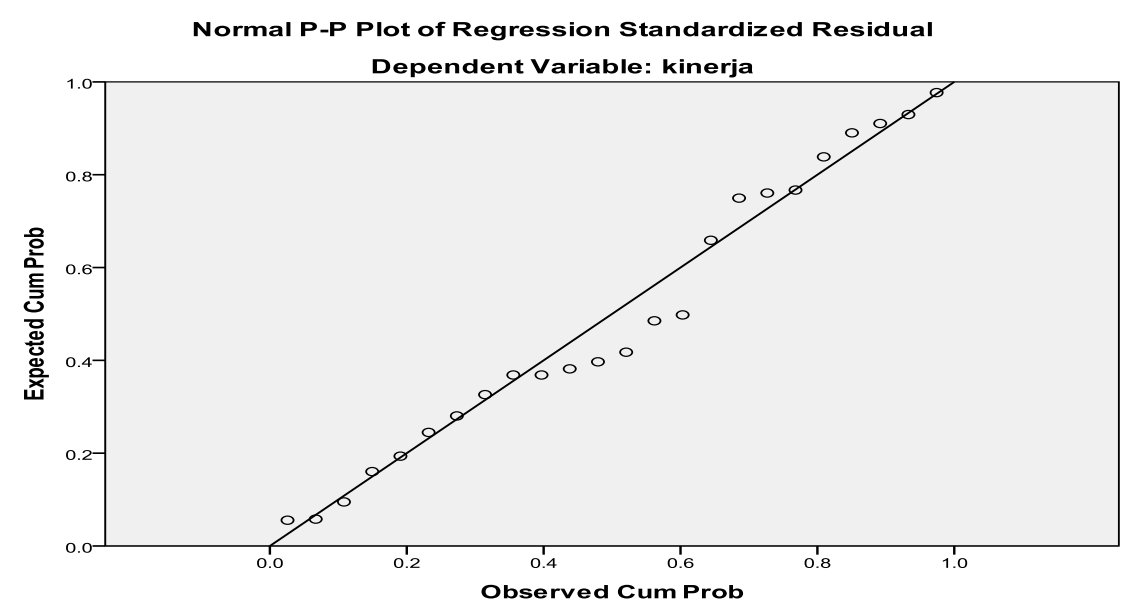


Hasil kurva normal probability plot memperlihatkan bahwa titik-titik pada grafik terhimpit dan mengikuti garis diagonalnya, sehingga dapat disimpulkan bahwa model regresi berdistribusi normal.

\section{Kurva normal P-P Plot Motivasi (X2) terhadap Kinerja (Y)}

Kurva normal $p-p$ plot untuk pengujian normalitas regresi linear antara motivasi terhadap kinerja dapat dilihat pada Gambar 6.

\section{Gambar 13 Kurva P-P Plot Motivasi (X2) terhadap Kinerja (Y)}

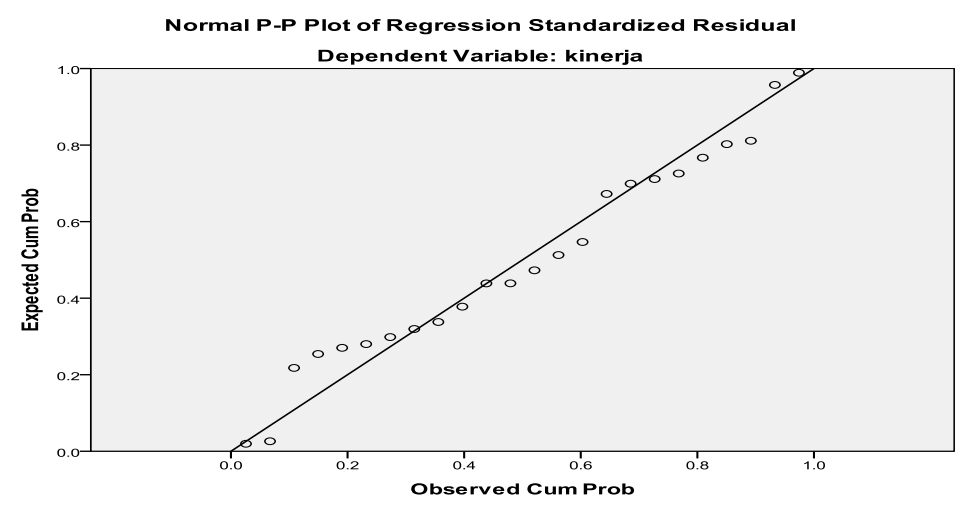

Hasil kurva normal probability plot memperlihatkan bahwa titik-titik pada grafik terhimpit dan mengikuti garis diagonalnya, sehingga dapat disimpulkan bahwa model regresi berdistribusi normal.

\section{Intepretasi Hasil Penelitian}

\section{Pengaruh Gaya Kepemimpinan terhadap Kinerja}

Dari hasil analisis data dan penelitian di lapangan, ada beberapa temuan dari penelitian ini, yaitu:

Gaya kepemimpinan tidak memiliki pengaruh positif dan nyata terhadap variabel kinerja karyawan LAZ MM Kota Bogor. Hal ini menunjukkan bahwa gaya kepemimpinan yang diterapkan belum maksimal sehingga belum terasa manfatatnya. Selain itu pemimpin cenderung memilih peran pasif dan membiarkan organisasi berjalan sendiri tanpa banyak mencampuri bagaimana organisasi berjalan. Oleh karena itu, gaya kepemimpinan harus ditingkatkan dan dikembangkan sesuai dengan gayagaya kepemimpinan yang bijak, guna meningkatkan kinerja karyawan LAZ MM Kota Bogor. 


\section{Pengaruh Motivasi terhadap Kinerja}

Motivasi memiliki pengaruh positif dan nyata terhadap variabel kinerja Motivasi dapat dinilai sebagai suatu daya dorong (driving force) yang menyebabkan orang dapat berbuat sesuatu untuk mencapai tujuan. Motivasi dapat digambarkan sebagai kemampuan untuk melaksanakan peran atau tugas, kemampuan mengintegrasikan pengetahuan, keterampilanketrampilan, sikap-sikap, dan nilai-nilai pribadi, serta kemampuan untuk membangun pengetahuan dan keterampilan yang didasarkan pada pengalaman dan pembelajaran yang dilakukan. Pegawai Lembaga Amil Zakat Marhamah Maimanah Kota Bogor mempunyai pengetahuan dan kemampuan memadai tentang teori dan cara fundraising, sehingga mempunyai pengaruh positif terhadap kinerja .

\section{Pengaruh Gaya Kepemimpinan dan Motivasi terhadap Kinerja}

Variabel gaya kepemimpinan dan motivasi tidak berpengaruh secara simultan terhadap kinerja. Hal ini ditunjukkan dari hasil koefisien determinasi kontribusi pengaruh terhadap peingkatan kinerja dijelaskan oleh gaya kepemimpinan dan motivasi $39,5 \%$ dan sisanya $(60,5 \%)$ dijelaskan oleh variabel-variabel lain di luar model dari penelitian ini.

Pengaruh yang paling dominan terhadap kinerja adalah dari motivasi. Hal ini membuktikan bahwa tinggi rendahnya kinerja karyawan LAZ MM sangat dipengaruhi oleh motivasi mereka dalam melaksanakan tugas yang telah diberikan sehingga dalam hal ini pemimpin harus mampu memilih gaya lain untuk menuntun para karyawan agar mampu bekerja sesuai dengan harapan dan selaras dengan pengembangan mutu LAZ MM kota Bogor di masa mendatang.

\section{SIMPULAN}

Berdasarkan hasil analisis dan pembahasan yang telah dilakukan dalam penelitian ini, maka dapat ditarik kesimpulan adanya pengaruh gaya kepemimpinan terhadap kinerja pegawai. Dari hasil perhitungan yang diperoleh t hitung untuk variabel gaya kepemimpinan sebesar 2,101 dengan tingkat signifikansi sebesar 0,047. Karena tingkat signifikansi lebih kecil dari 
0,05 berarti gaya kepemimpinan berpengaruh positif dan signifikan terhadap kinerja pegawai. Jadi dapat disimpulkan bahwa h1 diterima dan h0 ditolak.

Adanya pengaruh motivasi terhadap kinerja pegawai. Dari hasil perhitungan yang diperoleh $\mathrm{t}$ hitung untuk variabel motivasi sebesar 3,784>1,717 dengan tingkat signifikansi sebesar 0,001. Karena tingkat signifikansi lebih kecil dari 0,05 berarti motivasi berpengaruh positif dan signifikan terhadap kinerja pegawai. Jadi dapat disimpulkan bahwa h1 diterima dan h0 ditolak.

Adanya pengaruh gaya kepemimpinan dan motivasi secara bersamasama terhadap kinerja pegawai. Hasil perhitungan uji R2 menunjukkan bahwa koefisien determinasi (R2) yang diperoleh sebesar 0,395. Hal ini berarti 39,5\% kinerja pegawai dapat dijelaskan oleh variabel gaya kepemimpinan, dan motivasi kerja. Sedangkan sisanya sebesar 60,5\% (100\%-39,5\%), kinerja pegawai dijelaskan oleh variabel lain yang tidak dijelaskan dalam penelitian ini.

\section{DAFTAR PUSTAKA}

Ardana, Ikomang, Niwayan Mujiati, dan Wayan Murdiatha utama. (2012). Manajemen Sumber Daya Manusia. Yogyakarta: Graha IImu.

Arep, Ishak dan Hendri Tanjung. (2003). Manajemen Sumber Daya Manuisa. Jakarta: Universitas Trisakti.

Bachrun, Saifuddin (2011). Menghitung Tunjangan Insentif, Bonus dan Fasilitas. Jakarta: PPM

Danim. (2004). Motivasi dan Evektifitas Kelompok. Jakarta: PT Rineka Cipta

Dubrin. (2006). Leadership. Jakarta: Prenada Media.

Goleman, Bouatzis \& Anni McKee. (2007). Kepemimpinan Berdasarkan Kecerdasan Emosi. Jakarta: PT Gramedia Pustaka Utama.

Hafidhuddin, Didin dan Hendri Tanjung (2003). Manajemen Syariah dalam Praktik. Jakarta: Gema Insani

Hasibuan, Malayu S.P. (2005). Manajemen Sumber Daya Manusia. Jakarta: PT Bumi Aksara.

HASMI, DPP. (2010). Silsilah Tarbiyah Sunniyyah, Tugas dan Tujuan. Bogor: Hasmi. 
Heidjracman, Husnan. (2008). Manajemen Personalia. Yogyakarta: BPFEE YOGYAKARTA.

J.Simanjuntak,Payaman .(2011). Manajemen dan Evaluasi Kinerja. Jakarta:

Lembaga Penerbit Fakultas Ekonomi Universitas Indonesia.

Kortono. (2010). Pemimpin dan Kepemimpinan. Jakarta: Rajawali Pers.

Lubis. (2008). Total Motivasion. Yogyakarta: PRO-YOU.

Mangkuprawira, Sjafri. (2009). Bisnis, Manajemen dan Sumberdaya Manusia.IPB Press.

Mangkunegara, Anwar Prabu. (2008). Manajemen Sumber Daya Manusi Perusahaan. Bandung: PT. Remaja Rosdakarya.

Masyhudzulhak. (2012). Manajemen Sumber Daya Manusia. LP2S Lembaga Pengkajian dan Pengembangan Sumber Daya.

Meyer, Paul J. (2008). 5 Pilar Kepemimpinan. Jakarta Barat: Nafiri Gabriel.

Priyatna, M. (2015). Implementasi Manajemen pendidikan Berbasis Syariah di STAI Al-Hidayah Bogor. Jurnal Edukasi Islam, 4 (07), 787-805.

Priyatna, M. (2016). Manajemen pengembangan SDM pada lembaga pendidikan Islam. Jurnal Edukasi Islam, 5 (09), 1231-1250.

Rivai dan Mulyadi. (2009). Kepemimpinan dan Perilaku Organisasi. Jakarta: Rajawali Pers.

Rivai,Veithzal dan Ahmad Fawzi Mohd.Basri (2005). Performance Appraisal:

Sistem yang Tepat ubntuk menilai Kinerja Karyawan dan

Meningkatkan Daya Sain perusahaan. Jakarta. Rraja Grapindo Persada.

Raharjo,Joko (2013: 154). Paradigma Baru Manajemen Sumber Daya Manusia. Platinum.

Siagian, (2004). Teori Motivasi dan Aplikasinya. Jakarta: Rineka Cipta.

Sashkin,Marshall, Molly G. Sashkin. (2003). Prinsip-prinsip Kepemimpinan. Jakarta: Erlangga. 